Berkala Ilmu Perpustakaan dan Informasi, Vol. 13, No. 1, Juni 2017, Hal. 64-78 DOI: http://10.22146/bip.25968

ISSN 1693-7740 (Print), ISSN 2477-0361 (Online)

Tersedia online di https://jurnal.ugm.ac.id/bip

\title{
JABATAN FUNGSIONAL PUSTAKAWAN DI MATA PEGAWAI NON PUSTAKAWAN
}

\author{
Sungadi ${ }^{1}$ \\ ${ }^{1}$ Pustakawan Universitas Islam Indonesia \\ e-mail: sungadi@uii.ac.id
}

Naskah diterima: 4 Januari 2017, direvisi: 9 Mei 2017, disetujui: 12 Juni 2017

\begin{abstract}
ABSTRAK
Populasi pustakawan di lokasi penelitian (sebut Universitas A) dari waktu ke waktu semakin berkurang karena pensiun. Awalnya pustakawan Universitas A berjumlah 32 orang saat ini tinggal 25 orang dan 5 tahun ke depan di universitas tersebut tinggal memiliki 20-an pustakawan saja. Tujuan penelitian ini untuk mengetahui minat tenaga kependidikan non pustakawan menjadi pustakawan terkait tunjangan fungsional pustakawan dengan usia pensiun lebih lama. Responden penelitian tenaga kependidikan yang berijazah Sarjana (S1) sebanyak 43 orang. Metode penelitian ini adalah metode survei dengan pendekatan kuantitatif dengan analisis data menggunakan metode statistik. Rumus yang digunakan Korelasi Product Moment. Hasil penelitian menunjukkan bahwa yang menyatakan tidak berminat menjadi pustakawan sebanyak 24 orang (55.81\%), menyatakan ragu-ragu 12 orang (27.91\%), menyatakan minat 4 orang $(9.30 \%)$, dan menyatakan abstein sebesar 3 orang (6.97\%). Hubungan korelasi tingkat signifikansi diperoleh hasil variabel X. (Tunjangan Jabatan Fungsional Pustakawan) dengan variabel $X_{2}$ (Usia Pensiun Lebih Lama) nilai signifikansinya $0.101>0.05$ (0.101 lebih besar dari 0.05) yang berarti tidak ada korelasi (hubungan) yang signifikan. Korelasi antara variabel $X_{1}$ (Tunjangan Jabatan Fungsional Pustakawan) dengan variabel Y (Motivasi Menjadi Pustakawan) nilai signifikansinya $0.014<0.05$ (0.014 lebih kecil dari 0.05) yang berarti ada korelasi (hubungan) yang signifikan. Korelasi antara variabel $X_{2}$ (Usia Pensiun Lebih Lama) dengan variabel $Y$ (Motivasi Menjadi Pustakawan) nilai signifikansinya $0.003<0.05$ (0.003 lebih kecil dari 0.05) yang berarti ada korelasi (hubungan) yang sangat signifikan. Besarnya hubungan antara variabel tunjangan fungsional pustakawan dengan motivasi menjadi pustakawan sebesar 37,2\%, sedangkan untuk variabel usia penisun lebih lama dengan motivasimenjadi pustakawan sebesar $44,10 \%$.
\end{abstract}

Kata Kunci: Pustakawan, Tunjangan Fungsional, Usia Pensiun, Tenaga Kependidikan, Perpustakaan

\begin{abstract}
The number of librarians at the study site (called the University A) from time to time on the wane since pension. In the university A, some years ago, the number of librarians 32 people, however currently the number decreased to 25 people, and in the next 5 years the number will become 20. The purpose of this study was to determine the interest of staff (non librarian) to become a librarian which will lead to the longer time to work before retirement. The respondents with Bachelor Degree 43. This research used survey with quantitative approach and statistical analysis using Product Moment Correlation. The results showed that staff, who were not interested in becoming a librarian,were $24(55.81 \%)$, neutral 12 (27.91\%), interest expression $4(9.30 \%)$, and abstein $3(6.97 \%)$. The correlation level of significance of variabel $X_{1}$ (functional librarian) with variabel $X_{2}$ (longer age of retirement) was $0.101>0.05(0.101$ greater than 0.05$)$, which means there was no significant correlation. The correlation between variabels $X_{I}$ (functional librarian) with a variabel $Y$ (motivation to be a librarian) 0.014 significance value of $<0.05$ (0.014 less than 0.05), which means there was no significant correlation. The correlation between variabels $X_{2}$ (longer age of retirement) with variabel $Y$ (motivation to be a librarian) 0.003 with significance value of $<0.05$ (0.003 less than 0.05), which means there is no significant correlation. The magnitude of the relationship between the variabels of functional of librarian librarian and the motivation showed $37.2 \%$, while for the variabel of longer age of retirement showed $44.10 \%$.
\end{abstract}

Keywords: Librarian, Allowances Fungsional, Retirement Age, Personnel and Libraries 


\section{A. PENDAHULUAN}

\section{Latar Belakang}

Perpustakaan merupakan sebuah lembaga yang tumbuh dan berkembang dari sisi koleksi dan sumber daya manusia. Perpustakaan Perguruan Tinggi merupakan salah satu jenis perpustakaan yang ada di lingkungan masyarakat. Peran perpustakaan akan bermanfaat tergantung pada kinerja pustakawan dan sumber daya manusia lainnya. Keberadaan pustakawan sebagai tenaga fungsional tidak ada bedanya dengan pegawai non fungsional lain yang pada waktunya akan mengalami masa pensiun.

Dalam menyikapi pensiun pustakawan di masing-masing perpustakaan memiliki masalah yang berbeda antara perpustakaan satu dengan perpustakaan lainnya. Dalam penelitian ini penulis menemukan sebuah fenomena tersendiri (sebut saja Perpustakaan Universitas A). Universitas A merupakan salah satu perguruan tinggi swasta di Indonesia yang telah memberlakukan tenaga kependidikan sebagai pejabat fungsional. Diawali dengan adanya impasing pada tahun 1993, sudah banyak upaya yang dilakukan oleh Universitas A dalam membangkitkan minat para pegawai untuk menjadi pustakawan, antara lain dengan studi lanjut tingkat Diploma hingga Sarjana (S1). Selain itu, para pustakawan diberikan tunjangan fungsional, dan usia pensiun yang lebih tinggi dibandingkan dengan tenaga kependidikan non pustakawan yaitu antara 60 - 65 tahun, sedangkan tenaga kependidikan non fungsional akan dipensiun pada usia 55 tahun. Kurangnya minat tenaga kependidikan di Universitas A untuk menjadi pustakawan (alih jalur dari tenaga kependidikan non fungsional ke tenaga kependidikan fungsional, bukan karena kurangnya sosialisasi pemegang kebijakan di Universitas A, tetapi disebabkan oleh kurang tanggapnya tenaga kependidikan Universitas A,

sehingga masih banyak tenaga kependidikan yang belum mengetahui adanya tawaran alih jalur ini. Sejak diberlakukan tenaga kependidikan sebagai tenaga fungsional (1993) hingga sekarang baru ada satu (1) orang tenaga kependidikan yang beralih profesi ke tenaga kependidikan fungsional (pustakawan). Disamping itu setiap penerimaan pegawai baru belum pernah ada formasi untuk pustakawan. Dalam kasus ini tidak hanya terjadi di Universitas A tetapi juga terjadi di beberapa daerah, antara lain di Provinsi Kalimantan Barat, UNDIP Semarang, dan diberbagai kawasan di Indonesia Timur. Kasus di Provinsi Kalimantan Barat sebagaimana dimuat pada Kalbar Online 2012. Widanarta, tahun 2011 mengadakan penelitian terhadap petugas perpustakaan non pustakawan dan pustakawan di lingkungan UPT Perpustakaan UNDIP. Metode yang digunakan adalah metode survei dengan pendekatan kuantitatif. Dari hasil analisis data dapat diambil kesimpulan bahwa terdapat perbedaan hasil analisis untuk pustakawan dan non pustakawan, yaitu : 1. Untuk pustakawan, terdapat pengaruh yang positif dan signifikan antara tunjangan jabatan fungsional pustakawan dan batas usia pensiun terhadap motivasi menjadi pustakawan. 2. Untuk non pustakawan, tidak terdapat pengaruh yang positif dan signifikan antara tunjangan jabatan fungsional pustakawan dan batas usia pensiun terhadap motivasi menjadi pustakawan.

Saputro (2006) menyatakan bahwa masih rendahnya minat untuk menjadi pustakawan dipengaruhi oleh beberapa fenomena yang terjadi ditengah-tengah masyarakat. Pertama, sebagian besar PNS lebih mendambakan jabatan struktural daripada jabatan fungsional pustakawan. Selain tunjangan jabatan struktural lebih besar, faktor "gengsi" atau prestise juga turut berperan. Lagi pula, pejabat struktural lebih berpeluang untuk mendapat tambahan fasilitas dan "penghasilan". Kedua, tunjangan jabatan fungsional pustakawan tidak berbeda jauh dengan tunjangan staf umum. Padahal, beban pekerjaan seorang pustakawan jelas lebih tinggi daripada staf umum. Hal inilah yang sering dirasakan kurang adil oleh teman-teman pustakawan. Ketiga, panjangnya birokrasi pengurusan penetapan angka kredit (PAK). Pustakawan di perpustakaan daerah untuk mengurus PAK harus ke Perpustakaan Daerah Provinsi karena pemerintah daerah belum memiliki Tim Penilai Angka Kredit sendiri. Untuk membentuk tim penilai angka kredit setidaknya harus ada 15 orang pustakawan di sebuah daerah. Keempat, problematika angka kredit. Angka kredit untuk kegiatan rutin pustakawan tergolong rendah. Melakukan klasifikasi sederhana setiap judul hanya dihargai 0,003 angka kredit. Sementara itu, untuk klasifikasi kompleks setiap judul hanya dihargai 0,007 angka kredit. Hal ini berarti jika seorang pustakawan melakukan klasifikasi 1.000 (seribu) judul buku, hanya akan memperoleh tiga sampai tujuh angka kredit.

Kasus pertama dan ketiga tersebut tidak berlaku di Universitas A, karena di Universitas A sampai saat ini masih berlaku adanya jabatan ganda yaitu jabatan struktural dan jabatan fungsional pustakawan dimana seorang pustakawan boleh merangkap kedua jabatan tersebut. Sementara Universitas A sejak memberlakukan tenaga kependidikan sebagai tenaga fungsional telah 
memiliki Tim Penilai Angka Kredit bagi pustakawan yang independen, dan untuk birokrasi pengurusan penetapan angka kredit (PAK) menurut hemat peneliti tidak terlalu panjang. Mungkin pada kasus ke empat hampir dirasakan oleh sebagian besar pustakawan di Indonesia terkait kecilnya angka kredit, akan tetapi bagi pustakawan yang rajin hal tersebut bukan merupakan sebuah masalah.

Selanjutnya pada Peraturan Universitas A Nomor 15/PU/REK/IX/2010 tentang Jabatan Fungsional, Pangkat dan Angka Kredit Pustakawan Universitas A, Pasal 30 menjelaskan bahwa batas usia pensiun putakawan Universitas A adalah bagi Pustakawan Madya dan Pustakawan Utama akan memasuki pensiun pada usia 65 tahun, sedangkan Pustakawan Penyelia sampai dengan Pustakawan Muda akan dipensiun pada usia 60 tahun.

Berdasarkan uraian di atas adanya tambahan berupa tunjangan jabatan fungsional pustakawan yang cukup besar dan batas usia pensiun yang lebih lama, sehingga kesejahteraan hidup dihari tua lebih terjamin dan bisa terus mendapatkan penghasilan dari pekerjaannya sampai batas usia pensiun terakhir. Jika tunjangan jabatan fungsional pustakawan dan batas usia pensiun yang lebih lama memang dianggap bernilai lebih, dapat diasumsikan hal ini akan membuat para tenaga kependidikan Universitas A termotivasi untuk menjadi pustakawan.

\section{Permasalahan}

Permasalahan penelitian ini apakah dengan tunjangan fungsional pustakawan dan batas usia pensiun yang lebih lama berpengaruh terhadap motivasi tenaga kependidikan non fungsional Universitas A untuk menjadi pustakawan?

\section{Tujuan} adalah :

Berdasarkan uraian diatas, tujuan penelitian

1. Untuk menganalisis dan membuktikan apakah tunjangan jabatan fungsional pustakawan berpengaruh terhadap motivasi tenaga kependidikan non pustakawan Universitas A untuk menjadi pustakawan.

2. Untuk menganalisis dan membuktikan apakah batas usia pensiun pustakawan yang lebih lama berpengaruh terhadap motivasi tenaga kependidikan non pustakawan Universitas A untuk menjadi pustakawan.

3. Untuk menganalisis dan membuktikan apakah tunjangan jabatan fungsional pustakawan mempunyai hubungan yang positif dan signifikan dengan batas usia pensiun.
4. Untuk menganalisis dan membuktikan apakah tunjangan jabatan fungsional pustakawan dan batas usia pensiun yang lebih lama berpengaruh terhadap motivasi tenaga kependidikan non pustakawan Universitas A untuk menjadi pustakawan.

\section{B. TINJAUAN PUSTAKA}

\section{Pustakawan}

Banyak orang belum mengenal istilah pustakawan, dimata mereka orang yang bekerja di perpustakaan adalah petugas perpustakaan. Anggapan itu tidaklah salah, memang kenyataannya masih banyak petugas perpustakaan atau tenaga teknis perpustakaan yang bukan pustakawan. Walaupun tenaga teknis perpustakaan sendiri dapat dirangkap oleh pustakawan. Tetapi hal ini juga perlu diluruskan bahwa pustakawan dengan petugas perpustakaan itu berbeda. "Pustakawan adalah seseorang yang memiliki kompetensi yang diperoleh melalui pendidikan dan/ atau pelatihan kepustakawan dan serta mempunyai tugas dan tanggung jawab untuk melaksanakan pengelolaan dan pelayanan perpustakaan" (Undang-Undang Republik Indonesia No.43 Tahun 2007 tentang Perpustakaan dalam pasal 1 ayat 8). Pengertian lain mengatakan bahwa : Pustakawan adalah pegawai negeri sipil yang berijazah di bidang perpustakaan, dokumentasi, dan informasi yang diberi tugas secara penuh oleh pejabat yang berwenang untuk melakukan kegiatan perpustakaan dan dokumentasi pada unit-unit perpustakaan instansi pemarintah dan atau unit-unit tertentu lainnya (Soeatminah, 2002).

Bardasarkan Kepmenpan Nomor 132/KEP/M.PAN/12/2002 dan PERMENPAN-RB RI Nomor 9 tahun 2014 tentang Jabatan Fungsional Pustakawan Dan Angka Kreditnya menyatakan bahwa: Pejabat fungsional Pustakawan yang selanjutnya disebut Pustakawan adalah Pegawai Negeri Sipil yang diberi tugas, tanggung jawab, wewenang, dan hak secara penuh oleh pejabat yang berwenang untuk melakukan kegiatan kepustakawanan pada unit-unit perpustakaan, dokumentasi dan informasi instansi pemerintah dan atau unit tertentu lainnya.

Kemudian menurut Sulistyo-Basuki (2010) Pustakawan ialah orang yang memberikan dan melaksan akan kegiatan perpustakaan dalam usaha pemberian layanan kepada masyarakat sesuai dengan misi yang diemban oleh badan induknya berdasarkan ilmu perpustakaan, dokumentasi, dan informasi yang diperolehnya melalui pendidikan. 
Sedangkan petugas perpustakaan adalah pegawai negeri sipil atau honorer yang belum mendapatkan ijazah di bidang ilmu perpustakaan, dokumentasi, dan informasi tetapi ditempatkan atau ditugaskan untuk bekerja di instansi perpustakaan, dokumentasi, dan informasi. Jadi dapat disimpulkan bahwa petugas perpustakaan belum berarti seorang pustakawan yang juga mendapatkan tunjangan jabatan fungsional pustakawan.

\section{Tunjangan Jabatan Fungsional Pustakawan}

Pagawai yang sudah mendapatkan jabatan fungsional pustakawan tentunya juga mendapatkan tunjangan jabatan fungsional pegawai negeri sipil. Karena seperti yang telah dijelaskan diatas pustakawan merupakan pegawai negeri sipil dan setiap pegawai negeri sipil apapun jabatan fungsionalnya berhak atas tunjangan tersebut. Selanjutnya menurut Peraturan Presiden Republik Indonesia Nomor 71 Tahun 2013 tentang Tunjangan Jabatan Fungsional Pustakawan menyebutkan bahwa : Dalam Peraturan Presiden tersebut yang dimaksud dengan Tunjangan Jabatan Fungsional Pustakawan, yang selanjutnya disebut dengan Tunjangan Pustakawan adalah tunjangan jabatan fungsional yang diberikan kepada Pegawai Negeri Sipil yang diangkat dan ditugaskan secara penuh dalam Jabatan Fungsional Pustakawan sesuai dengan ketentuan peraturan perundang-undangan.

Tunjangan jabatan fungsional pustakawan ini diberikan setiap bulan dan besarnya tunjangan berbeda-beda setiap tingkatan pustakawan. Untuk pelaksanaan pemberian tunjangan fungsional tersebut dilakukan oleh Direktorat Jenderal Perbendaharaan Kementerian Keuangan RI.

Selanjutnya besar tunjangan yang diberikan mengalami beberapa perubahan dari tahun ke tahun mulai dari pertama kali peraturan dibuat pada tahun 1992 dan terus mengalami perubahan sampai yang terakhir pada tahun 2013. Ini terjadi karena adanya perubahan mengenai kebijakan-kebijakan yang mengatur tentang tunjangan jabatan fungsional pustakawan. Sedikitnya terdapat 6 (enam) kali perubahan peraturan tentang tunjangan jabatan fungsional pustakawan.

Pertama adalah Keputusan Presiden Republik Indonesia Nomor 65 Tahun 1992 tentang Tunjangan Jabatan Pustakawan, Teknisi Penerbangan, Penguji Mutu Barang, dan Pranata Komputer. Kedua pada tahun 2000 terjadi perubahan peraturan menjadi Keputusan Presiden Republik Indonesia Nomor 146 Tahun 2000 tentang Tunjangan Jabatan Fungsional Pustakawan. Ketiga pada tahun 2003 terdapat peraturan baru yang mengganti peraturan sebelumnya yaitu Keputusan Presiden Republik Indonesia Nomor 86 Tahun 2003 tentang Tunjangan Jabatan Fungsional Pustakawan. Keempat adalah Peraturan Presiden Republik Indonesia Nomor 40 Tahun 2006 tentang Tunjangan Jabatan Fungsional Arsiparis dan Pustakawan. Kelima adalah Peraturan Presiden Republik Indonesia Nomor 47 Tahun 2007 tentang Tunjangan Jabatan Fungsional Pustakawan. Keenam adalah Peraturan Presiden Republik Indonesia Nomor 71 Tahun 2013 tentang Tunjangan Jabatan Fungsional Pustakawan.

Dari keenam peraturan tersebut, besaran tunjangan fungsional pustakawan dapat dijabarkan pada tabel 1. Dari tabel 1 tampak bahwa tunjangan jabatan fungsional pustakawan dari waktu ke waktu mengalami kenaikan yang signifikan yaitu berkisar antara $62-68 \%$, tergantung tingkat jabatan fungsional pustakawan.

Pustakawan tingkat ahli (Pustakawan Utama, Pustakawan Madya, Pustakawan Muda, dan Pustakawan Pertama) ada kenaikan rata-rata $65 \%$. Sementara Pustakawan tingkat terampil (Pustakawan Penyelia, Pustakawan Pelaksana Tingkat Lanjutan, dan Pustakawan Pelaksana) dengan rata-rata kenaikan $65,33 \%$. Dengan perbaikan tunjangan jabatan fungsional pustakawan yang diterima setiap bulannya, maka diharapkan akan berpengaruh positif terhadap kinerja dan karier pustakawan.

Tabel 1

Besaran Kenaikan Tunjangan Jabatan Fungsional Pustakawan Tahun 1992-2013

\begin{tabular}{|c|c|c|c|c|c|c|c|c|}
\hline \multirow{2}{*}{ No } & \multirow{2}{*}{ Nama Jabatan } & \multicolumn{6}{|c|}{ Tahun dan Besaran Tunjangan Jabatan Fungsional (Rp) } & \multirow{2}{*}{$\begin{array}{c}\text { Rerata } \\
\text { kenaikan (\%) }\end{array}$} \\
\hline & & 1992 & 2000 & 2003 & 2006 & 2007 & 2013 & \\
\hline 1 & Pust. Utama & 110.000 & 185.000 & 500.000 & 550.000 & 700.000 & 1.300 .000 & 64 \\
\hline 2 & Pust. Madya & 95.000 & 152.500 & 375.000 & 413.000 & 500.000 & 1.100 .000 & 64 \\
\hline 3 & Pust. Muda & 77.500 & 122.500 & 275.000 & 303.000 & 375.000 & 800.000 & 65 \\
\hline 4 & Pust. Pertama & 67.500 & 112.500 & 175.000 & 202.000 & 275.000 & 520.000 & 67 \\
\hline 5 & Pust. Penyelia & 57.500 & 122.500 & 200.000 & 220.000 & 350.000 & 700.000 & 62 \\
\hline 6 & Pust. Pelaksana Lanjutan & 47.500 & 112.500 & 150.000 & 202.000 & 265.000 & 420.000 & 66 \\
\hline 7 & Pust. Pelaksana & 42,500 & 102.500 & 120.000 & 197.000 & 240.000 & 350.000 & 68 \\
\hline
\end{tabular}

Sumber: Peraturan Presiden RI Tahun 1992-2013 diolah penulis 


\subsection{Fungsi dan Peran Tunjangan Jabatan Fungsional Pustakawan}

Pemberian tunjangan jabatan fungsional pustakawan secara adil dan layak akan mempunyai pengaruh yang sangat besar terhadap kelangsungan hidup perpustakaan. Menurut Martoyo (1990), fungsi pemberian kompensasi atau tunjangan jabatan fungsional pustakawan dalam suatu perpustakaan adalah sebagai berikut :

1. Pengalokasian sumber daya manusia (SDM) secara efisien.

Pemberian tunjangan fungsional pustakawan secara adil dan layak kepada pustakawan yang berprestasi akan mendorong pustakawan untuk bekerja lebih baik. Dengan kata lain ada kecenderungan para pustakawan akan berpindah ke pekerjaan yang tunjangannya lebih tinggi dengan cara menunjukan prestasi kerja yang lebih baik.

2. Penggunaan Sumber Daya Manusia Secara Lebih Efisien dan Efektif.

Pemberian tunjangan fungsional kepada pustakawan berimplikasi bahwa perpustakaan akan menggunakan tenaga pustakawan tersebut dengan seefisien dan seefektif mungkin. Sebab dengan cara demikian, perpustakaan yang bersangkutan akan memperoleh manfaat dan/ atau keuntungan semaksimal mungkin. Disinilah produktivitas pegawai sangat menentukan.

3. Mendorong stabilitas dan pertumbuhan perpustakaan;

Fungsi ini tentunya akan berkontribusi terhadap meningkatnya mutu pelayanan perpustakaan. Dengan adanya penjenjangan tingkat tunjangan fungsional, dimana semakin tinggi jabatan pustakawan, maka akan semakin tinggi tunjangan jabatan yang akan diperolehnya. Hal ini akan berimplikasi pada produktivitas kerja pustakawan menjadi naik, dengan demikian pertumbuhan perpustakaan juga akan berjalan secara baik pula. Dengan memanfaatkan SDM secara efektif maka akan mendorong terjadinya stabilitas dan pertumbuhan perpustakaan kearah yang positif. Bayangkan jika pemberian tunjangan fungsional tidak tepat tentu akan menyebabkan perpustakaan labil dan mudah goncang.

Selanjutnya menurut Hasan (2002) pemberian kompensasi atau tunjangan jabatan fungsional pustakawan mempunyai peran positif bagi pustakawan maupun perpustakaan antara lain :
1. Sebagai jaminan ekonomi (economy security) bagi pustakawan dan keluarganya.

2. Sebagai motivasi untuk meningkatkan prestasi kerja.

3. Sebagai penjaga keseimbangan antara kompensasi yang diberikan dengan prestasi kerja.

4. Sebagai alat kontrol bagi perpustakaan.

\subsection{Tujuan Pemberian Tunjangan Jabatan Fungsional Pustakawan}

Tujuan pemberian tunjangan jabatan fungsional pustakawan menurut Martoyo (1990) adalah :

1. Pemenuhan kebutuhan ekonomi.

Pustakawan yang menerima tunjangan jabatan fungsional pustakawan akan menggunakannya untuk memenuhi kebutuhan hidup sehariharinya dengan kata lain kebutuhan ekonominya.

2. Pengkaitan tunjangan dengan produktivitas kerja.

Pemberian tunjangan jabatan fungsional pustakawan yang lebih baik akan mendorong pustakawan untuk meningkatkan produktivitas kerjanya.

3. Pengkajian antara keseimbangan keadilan pemberian tunjangan.

Ini berarti bahwa pemberian tunjangan jabatan fungsional pustakawan harus diperbandingkan dengan persyaratan yang harus dipenuhi oleh pustakawan. Sehingga ada keseimbangan antara input (syarat yang harus dipenuhi) dengan output (tunjangan fungsional pustakawan). Sebab pemberian tunjangan yang tinggi hanya mungkin apabila syarat yang harus dipenuhi juga pada tingkat kepangkatan yang lebih tinggi.

\subsection{Batas Usia Pensiun Pustakawan}

Pensiun adalah hal yang pasti dialami oleh pegawai negeri maupun swasta jika sudah memasuki usia non produktif atau usia senja yang sudah berkurang frekuensi pekerjaan yang bisa dilakukan. Pensiun atau jaminan hari tua merupakan upaya pemerintah atau lembaga yang bertujuan untuk memberikan penghasilan kepada pegawai atau karyawan yang telah setia mengabdi dan berjasa kepada negara atau lembaga Tayibnapis (1994).

Berdasarkan Undang-undang Nomor 11 tahun 1969 tentang pensiun pegawai dan pensiun janda/ 
dudanya PNS, pensiun diberikan sebagai jaminan hari tua dan sebagai penghargaan atas jasa-jasa pegawai negeri selama bertahun-tahun bekerja dalam dinas pemerintah. Pada pokoknya adalah menjadi kewajiban setiap orang untuk berusaha menjamin hari tuanya, dan untuk ini setiap pegawai negeri sipil wajib menjadi peserta dari suatu badan asuransi sosial yang dibentuk oleh pemerintah. Karena pensiun bukan saja sebagai jaminan hari tua, tetapi juga adalah sebagai balas jasa, maka pemerintah memberikan sumbangannya kepada pegawai negeri.

Latar belakang adanya masa pensiun antara lain menurut Subid Pensiun (2011) adalah: 1. Karena batas usia pension; 2. Kemauan sendiri; 3. Takdir misalnya : sakit, meninggal dunia; 4 . Rekturisasi/Dinas; 5. Diberhentikan dengan tidak hormat karena adanya kasus. Sedangkan untuk unsur sifat pensiun adalah: 1 . Penghargaan, diberhentikan dengan hormat; 2. Jaminan hari tua; 3. Jasa terhadap Negara atau pemerintah. Selanjutnya tujuan dari program pensiun itu sendiri adalah : 1. Untuk memberikan jaminan hari tua bagi pegawai negeri/ peserta pada saat mencapai usia pension; 2. Sebagai penghargaan atas jasa-jasa pegawai negeri / peserta setelah yang bersangkutan memberikan pengabdian kepada Negara.

Menurut Undang-undang Nomor 11 tahun 1969 tentang pensiun pegawai dan pensiun janda/ dudanya PNS pasal 9, hak atas pensiun pegawai yang diberhentikan dengan hormat sebagai pegawai negeri sipil berhak menerima pensiun pegawai, jikalau ia pada saat pemberhentiannya sebagai pegawai :

1. Telah mencapai usia sekurang-kurangnya 50 tahun dan mempunyai masa kerja untuk pensiun sekurang-kurangnya 20 tahun.

2. Mempunyai masa kerja sekurang-kurangnya 4 tahun dan oleh badan/ pejabat yang ditunjuk oleh departemen kesehatan berdasarkan peraturan tentang pengujian kesehatan pegawai negeri, dinyatakan tidak dapat bekerja lagi dalam jabatan apapun juga karena keadaan jasmani atau rohani yang tidak disebabkan oleh dan karena ia menjalankan kewajiban jabatannya.

3. Pegawai negeri yang setelah menjalankan suatu tugas negara tidak dipekerjakan kembali sebagai pegawai negeri, berhak menerima pensiun pegawai apabila ia diberhentikan dengan hormat sebagai pegawai negeri dan pada saat pemberhentiannya sebagai pegawai negeri ia telah mencapai 20 usia sekurang-kurangnya
50 tahun dan memiliki masa kerja untuk pensiun sekurang-kurangnya 10 Tahun.

Setiap pegawai mempunyai hak pensiun atau batas usia pensiun yang berbeda-beda sesuai dengan jabatan fungsional masing-masing. Oleh karena itu jenis pensiun dapat dibedakan menjadi 4,yaitu : 1 . Non Batas Usia Pensiun (Non BUP); 2. Batas Usia Pensiun (BUP), PNS yang telah mencapai BUP harus diberhentikan dengan hormat sebagai PNS; 3. Pensiun Janda/ Duda; 4. Pensiun Anak.

Batas usia pensiun untuk pustakawan menurut Keputusan Presiden Republik Indonesia Nomor 102 Tahun 2003 menyatakan bahwa batas usia pensiun bagi putakawan adalah:

1. 65 (enam puluh lima) tahun bagi Pustakawan Utama;

2. 60 (enam puluh tahun) bagi:

a. Pustakawan Madya;

b. Pustakawan Muda;

c. Pustakawan Penyelia.

Sedangkan usia pensiun untuk pegawai negeri sipil umum adalah 56 tahun.

Menurut Tayibnapis (1994) pemberian hak pensiun kepada pegawai negeri sipil dapat dibedakan menjadi 2 , yaitu :

1. Percepatan pensiun.

Permohonan berhenti dengan hak pensiun yang diajukan oleh pegawai yang telah memenuhi syarat yakni berusia sekurang-kurangnya 50 tahun dan masa kerja telah mencapai 20 tahun. Pensiun ini sering disebut optional retirement.

2. Pensiun karena telah mencapai batas usia pensiun.

Pegawai mengajukan permohonan berhenti dengan hak pensiun kerena telah mencapai batas usia pensiun yang telah ditetapkan. Pensiun ini sering disebut compulsary retirement.

Namun tidak semua pegawai yang memiliki usia dan masa kerja yang sama akan memasuki masa pensiun yang sama pula. Hal ini dikarenakan adanya beberapa jenis keahlian yang mengakibatkan diterbitkannya ketetapan perpanjangan batas usia pensiun bagi pemangku jabatan tertentu.

Sementara menurut Peraturan Universitas UII Nomor 15/PU/REK/IX/2010 Pasal 30 menyatakan bahawa:

1. Pustakawan dengan jabatan Pustakawan Pelaksana Lanjutan atau Pustakawan Pertama dengan Pangkat Penata Muda Tingkat I, golongan/ruang III/b dengan usia 54 tahun 
berhak atas Masa Persiapan Pensiun dan akan dipensiun pada usia 55 tahun.

2. Pustakawan dengan jabatan fungsional Pustakawan Penyelia atau Pustakawan Muda dengan Pangkat Penata, golongan/ruang III/c dengan usia 59 tahun berhak atas Masa Persiapan Pensiun dan akan dipensiun pada usia 60 tahun.

3. Pustakawan dengan jabatan fungsional serendah-rendahnya Pustakawan Madya dengan usia 64 tahun berhak atas Masa Persiapan Pensiun dan akan dipensiun pada usia 65 tahun.

Dari uraian diatas dapat dipahami bahwa pustakawan yang telah memiliki jabatan fungsional minimal Pustakawan Madya dengan Pangkat Pembina, golongan/ruang IV/a maka mereka akan mendapat masa pensiun pada usia 65. Dalam hal ini terdapat perbedaan usia yang sangat signifikan yaitu selama 10 tahun antara pegawai kependidikan fungsional pustakawan dengan tenaga kependidikan non fungsional pustakawan.

\section{Motivasi}

Motivasi adalah kondisi psikologis dari dalam diri seseorang yang mendorong untuk melakukan sesuatu dan berperilaku secara tertentu terutama di dalam lingkungan ia bekerja. Motivasi juga bisa dikatakan sebagai rencana atau keinginan untuk menuju kesuksesan dan menghindari kegagalan hidup.

Dari segi etimologis menurut Winardi (2002) motivasi berasal dari kata 'movere' dalam bahasan latin yang berarti bergerak atau menggerakan, yaitu bergerak berdasarkan keingingan, harapan, kebutuhan, tujuan,dorongan, sasaran, dan insentif. Menurut Mc.Donald seperti dikutip oleh Sardiman (1988) "motivasi adalah perubahan energi dalam diri seseorang yang ditandai dengan munculnya 'feeling' dan didahului dengan tanggapan terhadap adanya tujuan". Pengertian lain dari Siagian (1989) menyakatan bahwa:

Motivasi adalah daya pendorong yang mengakibatkan seseorang anggota organisasi mau dan rela untuk mengerahkan kemampuan-dalam bentuk keahlian atau keterampilan-tenaga dan waktunya untuk menyelenggarakan berbagai kegiatan yang menjadi tanggung jawabnya dan menunaikan kewajibannya, dalam rangka pencapaian tujuan dan berbagai sasaran organisasi yang telah ditentukan sebelumnya.
Kemudian motivasi menurut Usman (2001) dapat dibedakan menjadi dua jenis motivasi, yaitu:

1. Motivasi Intrinsik

Jenis motivasi ini timbul sebagai akibat dari dalam diri individu sendiri tanpa ada paksaan dorongan dari oranglain, tetapi atas kemampuan sendiri.

2. Motivasi Ekstrinsik

Jenis motivasi ini timbul sebagai akibat pengaruh dari luar individu, apakah karena adanya ajakan, suruhan atau paksaan dari orang lain sehingga dengan kondisi yang demikian akhirnya ia mau melakukan sesuatu atau belajar. Dalam penelitian ini motivasi yang mempengaruhi adalah pengaruh dari luar individu sendiri yaitu tunjangan jabatan fungsional dan batas usia pensiun. Sedangkan Chung \& Megginson dalam Gomes (2001) menjelaskan bahwa motivasi melibatkan faktor-faktor individual dan faktor-faktor organisasional.

Faktor-faktor individual diantaranya meliputi: 1. Kebutuhan-kebutuhan (needs), 2. Tujuan-tujuan ( goals $), 3$. Sikap (attitude), dan 4 . Kemampuan-kemampuan (abilities). Sedangkan faktor-faktor organisasional meliputi: 1 . Pembayaran atau gaji (pay), 2. Keamanan pekerjaan (job security), 3. Sesama pekerja (co-workers), 4. Pengawasan (supervision), 5. Pujian (praise), dan 6. Pekerjaan itu sendiri (job it self).

Winardi (2002) menjelaskan bahwa motivasi seseorang tergantung pada kekuatan motif-motif mereka. Motif kadang-kadang dinyatakan orang sebagai kebutuhan, keinginan, dorongan yang muncul dalam diri seseorang. Motif diarahkan ke arah tujuan-tujuan yang dapat muncul dalam kondisi sadar atau dalam kondisi di bawah sadar. Motif-motif merupakan tindakan 'mengapa' dari perilaku. Dan pada intinya bahwa motif-motif atau kebutuhan-kebutuhan merupakan penyebab terjadinya tindakan-tindakan.

\section{METODE PENELITIAN}

Penelitian dilakukan di Universitas A Yogyakarta. Pemilihan lokasi penelitian dengan mempertimbangkan beberapa aspek antara lain: masalah yang diteliti berada di Universitas A, Peneliti bekerja di Universitas A, dan dalam rangka efisiensi biaya, waktu dan tenaga. Penelitian dilakukan antara bulan Februari-Juni 2015.

Populasi dalam penelitian ini adalah tenaga kependidikan yang bertugas di lingkungan 
Universitas A yang berpendidikan Sarjana (S1) non perpustakaan sebagai subyek penelitian. Bersumber dari data pemilih tetap pemilihan rektor Universitas A tahun 2014, diperoleh data bahwa jumlah tenaga kependidikan yang memiliki jenjang pendidikan S1 adalah 58 orang. Peneliti mengambil seluruh populasi (sensus) untuk dijadikan subyek penelitian. Setelah dilakukan penyebaran angket (kuisioner) penelitian kepada responden sebanyak 58 orang, yang mengembalikan sebanyak 43 orang.

Teknik pengumpulan data dilakukan melalui studi dokumen, yaitu dengan cara menyebarkan kuesioner kepada tenaga kependidikan yang bertugas di lingkungan kampus terpadu Universitas A yang berpendikan Sarjana (S1) non perpustakaan dan berstatus non fungsional pustakawan.

Data yang diperoleh dari pengumpulan data dianalisis secara deskriptif kuantitatif yaitu dengan memaparkan data-data yang ada sedetail mungkin dengan memvisualiasikan ke dalam sebuah tabel, kemudian dilakukan pembahasan secara keseluruhan sehingga dapat diketahui dan dianalisis, kemudian dapat ditarik suatu kesimpulan dengan melalui beberapa tahapan antara lain:

1. Scoring

Merupakan kegiatan memberi score atau nilai sesuai ukuran-ukuran yang telah ditentukan dalam jawaban kuesioner.

2. Tabulasi

Tabulasi adalah proses memasukkan data pada tabel-tabel tertentu dan mengatur angka-angka serta menghitungnya, sehingga menjadi tabel frekuensi.

Rumus persentase dari frekuensi dalam penelitian ini menggunakan:

\begin{tabular}{|ll}
$\mathrm{N}=\frac{f}{n} \times 100 \%$ & $\begin{array}{l}\mathrm{N}=\text { Nilai Hasil } \\
\mathrm{f}=\text { Frekuensi } \\
\mathrm{n}=\text { Jumlah }\end{array}$ \\
\hline
\end{tabular}

Gambar 1: Rumus Persentase, (Singarimbun, 1994)

Untuk selanjutnya dalam proses analisis data akan digunakan statistik untuk menyederhanakan data penelitian dengan mencari data terendah dan data tertinggi, kemudian dicari rentangnya, maka lebar dan jumlah interval yang tepat dapat ditetapkan (Riduwan, 2003). Teknik analisis data antar variabel akan menggunakan Tabel Product Moment, yang meliputi:

1. Hubungan antara tunjangan fungsional dengan motivasi menjadi pustakawan.
2. Hubungan antara usia pensiun dengan motivasi menjadi pustakawan.

3. Hubungan antara tunjangan fungsional dan usia pensiun dengan motivasi menjadi pustakawan.

Analisis data antar variabel tersebut dapat ditampilkan dalam bentuk gambar sebagai berikut:

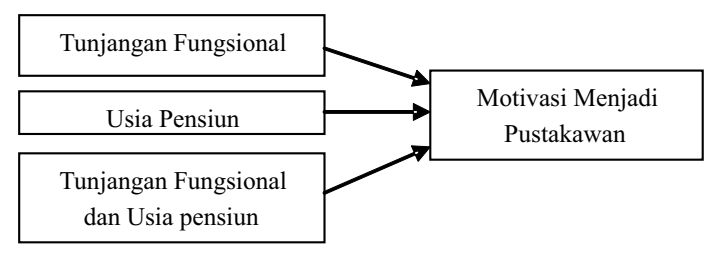

Gambar 2:

Skema Hubungan Variabel Bebas (Independen) dengan Variabel Terikat (Dependen)

\section{HASIL DAN PEMBAHASAN Temuan Penelitian}

Hasil penelitian yang dilakukan, mendeskripsikan dan menampilkan data dalam bentuk tabel distribusi frekuensi untuk semua variabel yaitu Tunjangan Jabatan Fungsional Pustakawan, Batas Usia Pensiun, dan Motivasi Menjadi Pustakawan. Berikut merupakan uraian analisis dan pembahasan penelitian.

Hasil penelitian yang mendeskripsikan hubungan tingginya tunjangan fungsional dan usia pensiun lebih lama dengan motivasi menjadi pustakawan studi kasus: tenaga kependidikan non pustakawan Universitas A diuraikan sebagai berikut.

\section{Jenis Kelamin}

Tabel 2 Jenis Kelamin Responden Tenaga Kependidikan Non Pustakawan Universitas A

\begin{tabular}{cccc}
\hline No & Jenis Kelamin & Jumlah & Persentase (\%) \\
\hline 1 & Laki-laki & 24 & 55.81 \\
2 & Perempuan & 18 & 41.86 \\
3 & Tidak Mengisi & 1 & 2.33 \\
\hline & Jumlah & 43 & 100 \\
\hline
\end{tabular}

Sumber: Data Primer 2015

Tabel 2 terlihat bahwa tenaga kependidikan non pustakawan Universitas A yang menjadi responden dalam penelitian ini berjenis kelamin laki-laki sebesar 24 orang (58.81\%), perempuan sebesar 18 orang $(41.86 \%)$, dan tidak mengisi 1 orang $(2.33 \%)$ 


\section{Usia}

Tabel 3 Usia Responden

Tenaga Kependidikan Non Pustakawan Universitas A

\begin{tabular}{cccc}
\hline No & Usia $(\mathrm{Th})$ & Jumlah & Persentase $(\%)$ \\
\hline 1 & Kurang dari 20 & 1 & 2.33 \\
2 & $20-29$ & 3 & 6.98 \\
3 & $30-39$ & 22 & 51.16 \\
4 & $40-49$ & 17 & 39.53 \\
\hline & Jumlah & 43 & 100
\end{tabular}

Sumber: Data Primer 2015

Tabel 3 menunjukkan bahwa usia Responden Tenaga Kependidikan non Pustakawan Universitas A yang menjadi responden dalam penelitian ini mayoritas berusia 30-39 tahun (51.16\%), disusul berturut berusia $40-49$ tahun sebesar 17 orang (39.53\%), usia 20-29 tahun sebesar 3 orang $(6.77 \%)$ dan usia kurang dari 20 tahun sebanyak 1 orang $(2.32 \%)$.

\section{Lama Bekerja}

Tabel 4 Lama Bekerja Responden Tenaga Kependidikan Non Pustakawan Universitas A

\begin{tabular}{cccc}
\hline No & Lama Bekerja (Th) & Jumlah & Persentase (\%) \\
\hline 1 & Kurang Dari 5 & 1 & 2.33 \\
2 & $6-10$ & 14 & 32.56 \\
3 & $11-15$ & 13 & 30.23 \\
4 & $16-20$ & 10 & 23.26 \\
5 & $21-25$ & 4 & 9.30 \\
6 & Tidak Mengisi & 1 & 2.33 \\
\hline & Jumlah & 43 & 100 \\
\hline
\end{tabular}

Sumber: Data Primer 2015

Tabel 4 menunjukkan bahwa lama bekerja Responden Tenaga Kependidikan Non Pustakawan Universitas A yang menjadi responden dalam penelitian ini mayoritas telah bekerja di perguruan tinggi tersebut selama antara 6-10 tahun sebanyak 14 orang $(32.56 \%)$, disusul berturut-turut lama bekerja antara 11-15 tahun sebesar 13 orang (30.23\%), lama bekerja antara 16-20 tahun sebesar 10 orang (23.26\%), lama bekerja antara 21-25 tahun sebesar 4 orang $(9.30 \%)$. Sementara lama bekerja kurang dari 5 tahun dan tidak mengisi masing-masing sebanyak 1 orang $(2.33 \%)$.

\section{Minat Menjadi Pustakawan}

Tabel 5 Minat Menjadi Pustakawan Responden Tenaga Kependidikan Non Pustakawan Universitas A

\begin{tabular}{|c|c|c|c|c|c|c|c|c|c|}
\hline \multirow[t]{2}{*}{ Ket } & \multicolumn{2}{|c|}{ Minat } & \multicolumn{2}{|c|}{ Tidak } & \multicolumn{2}{|c|}{ Ragu-Ragu } & \multicolumn{2}{|c|}{ Abstein } & \multirow[t]{2}{*}{ Total } \\
\hline & $\mathrm{L}$ & $\mathrm{P}$ & $\mathrm{L}$ & $P$ & $\mathrm{~L}$ & $\mathrm{P}$ & $\mathrm{L}$ & $\mathrm{P}$ & \\
\hline$\sum$ & 2 & 2 & 15 & 9 & 7 & 5 & 1 & 2 & 43 \\
\hline$\%$ & 4.65 & 4.65 & 34,88 & 20.93 & 16.28 & 11.63 & 2.33 & 4.65 & 100 \\
\hline$\sum \mathrm{L}+\mathrm{P}$ & & 4 & & & 12 & & & & 43 \\
\hline$\% \mathrm{~L}+\mathrm{P}$ & & 30 & & 81 & 27. & & & 97 & 100 \\
\hline
\end{tabular}

Tabel 5 menunjukkan bahwa minat menjadi Pustakawan Responden Tenaga Kependidikan Non Pustakawan Universitas A yang menjadi responden dalam penelitian ini yang menyatakan tidak berminat menjadi pustakawan sebanyak 24 orang (55.81\%) terdiri dari laki-laki 15 orang $(34.88 \%)$ dan perempuan 9 orang $(20.93 \%)$, yang menyatakan ragu-ragu 12 orang (27.91\%) terdiri atas laki-laki 7 orang $(16.28 \%)$ dan perempuan 5 orang $(11.63 \%)$, menyatakan minat sebanyak 4 orang $(9.30 \%)$ masing-masing 2 orang laki-laki dan wanita 2 orang $(4.65 \%)$, dan menyatakan abstein sebesar 3 orang $(6.97 \%)$ laki-laki 1 orang $(2.33 \%)$ dan perempuan 2 orang $(4.65 \%)$.

\section{Variabel Tunjangan Fungsional}

Tabel 6 Distribusi Frekuensi Variabel Tunjangan Fungsional $\left(\mathrm{X}_{1}\right)$

\begin{tabular}{cccc}
\hline No & Kategori & Frekuensi & Persentase (\%) \\
\hline 1 & Tinggi & 4 & 9.30 \\
2 & Sedang & 19 & 44.19 \\
3 & Rendah & 20 & 46.51 \\
\hline & Jumlah & 43 & 100 \\
\hline
\end{tabular}

Sumber: Data Primer Olahan 2015

Tabel 6 menunjukkan bahwa distribusi frekuensi variabel tunjangan fungsional $\left(\mathrm{X}_{1}\right)$ kategori rendah sebesar 20 orang (46.51\%). Disusul kategori sedang sebesar 19 orang $(44.19 \%)$, dan kategori tinggi sebesar 4 orang $(9.30 \%)$. 
Variabel Usia Pensiun Lebih Lama

Tabel 7 Distribusi Frekuensi Usia Pensiun Lebih Lama $\left(\mathrm{X}_{2}\right)$

\begin{tabular}{cccc}
\hline No & Kategori & Frekuensi & Persentase (\%) \\
\hline 1 & Tinggi & 7 & 16.28 \\
2 & Sedang & 21 & 48.84 \\
3 & Rendah & 15 & 34.88 \\
\hline & Jumlah & 43 & 100 \\
\hline
\end{tabular}

Sumber: Data Primer Olahan 2015

Tabel 7 menunjukkan bahwa distribusi frekuensi variabel usia pensiun lebih lama $\left(\mathrm{X}_{2}\right)$ kategori sedang sebesar 21 orang (48.84\%). Disusul kategori rendah sebesar 15 orang $(34.88 \%)$, dan kategori tinggi sebesar 7 orang $(16.28 \%)$.

\section{Variabel Motivasi Menjadi Pustakawan}

Tabel 8 Distribusi Frekuensi Motivasi Menjadi Pustakawan (Y)

\begin{tabular}{cccc}
\hline No & Kategori & Frekuensi & Persentase (\%) \\
\hline 1 & Tinggi & 7 & 16.28 \\
2 & Sedang & 29 & 67.44 \\
3 & Rendah & 7 & 16.28 \\
\hline & Jumlah & 43 & 100
\end{tabular}

Sumber: Data Primer Olahan 2015

Tabel 8 menunjukkan bahwa distribusi frekuensi variabel motivasi menjadi pustakawan $(\mathrm{Y})$ kategori sedang sebesar 29 orang (67.44\%). Disusul kategori tinggi sebesar 7 orang (16.28\%), dan kategori rendah sebesar 7 orang $(16.28 \%)$.

\section{Uji Validitas dan Reliabilitas Uji Validitas}

Uji validitas bertujuan untuk mengukur sejauh mana ketepatan suatu alat ukur melakukan fungsi ukurnya. Teknik yang digunakan untuk uji validitas adalah Pearson Product Moment. Pengujian validitas dilakukan dengan responden sebanyak 43 responden. Dalam pengujian ini koefisien korelasi kritis diperoleh dari tabel distribusi $\mathrm{r}$ pada taraf signifikansi sebesar 5\% diperoleh nilai $\mathrm{r}$-tabel $=0.301$. Uji signifikansi dilakukan dengan membandingkan nilai $r_{\text {hitung }}$ dengan $r_{\text {tabel. }}$. Jika $r$ hitung (untuk $r$ tiap butir pertanyaan terhadap skor total) lebih besar dari $r$ tabel, maka butir atau pertanyaan tersebut dikatakan valid. Hasil Uji Validitas dapat ditunjukkan pada tabel berikut:
Tabel 9 Hasil Uji Validitas

\begin{tabular}{|c|c|c|c|c|}
\hline Variabel & Item & $\mathrm{r}_{\text {tabel }}$ & $\begin{array}{c}\text { Koefisien } \\
\text { Korelasi } \\
\end{array}$ & Keterangan \\
\hline Tunjangan & Soall & 0.301 & .518 & Valid \\
\hline \multirow[t]{7}{*}{ Fungsional } & Soal2 & 0.301 & .518 & Valid \\
\hline & Soal3 & 0.301 & .585 & Valid \\
\hline & Soal4 & 0.301 & .546 & Valid \\
\hline & Soal5 & 0.301 & .628 & Valid \\
\hline & Soal6 & 0.301 & .518 & Valid \\
\hline & Soal8 & 0.301 & .464 & Valid \\
\hline & Soal9 & 0.301 & .410 & Valid \\
\hline \multirow{16}{*}{$\begin{array}{l}\text { Usia Pensiun } \\
\text { Lebih Lama }\end{array}$} & Soall & 0.301 & .255 & Tidak Valid \\
\hline & Soal2 & 0.301 & .641 & Valid \\
\hline & Soal3 & 0.301 & .623 & Valid \\
\hline & Soal4 & 0.301 & .613 & Valid \\
\hline & Soal5 & 0.301 & .599 & Valid \\
\hline & Soal6 & 0.301 & .494 & Valid \\
\hline & Soal7 & 0.301 & .430 & Valid \\
\hline & Soal8 & 0.301 & .508 & Valid \\
\hline & Soal9 & 0.301 & .363 & Valid \\
\hline & Soal10 & 0.301 & .455 & Valid \\
\hline & Soal11 & 0.301 & .543 & Valid \\
\hline & Soal12 & 0.301 & .613 & Valid \\
\hline & Soal13 & 0.301 & .406 & Valid \\
\hline & Soal14 & 0.301 & .334 & Valid \\
\hline & Soal15 & 0.301 & .507 & Valid \\
\hline & Soal16 & 0.301 & .534 & Valid \\
\hline \multirow{15}{*}{$\begin{array}{c}\text { Motivasi } \\
\text { Menjadi } \\
\text { Pustakawan }\end{array}$} & Soall & 0.301 & .700 & Valid \\
\hline & Soal2 & 0.301 & .831 & Valid \\
\hline & Soal3 & 0.301 & .742 & Valid \\
\hline & Soal4 & 0.301 & .794 & Valid \\
\hline & Soal5 & 0.301 & .832 & Valid \\
\hline & Soal6 & 0.301 & .824 & Valid \\
\hline & Soal7 & 0.301 & .853 & Valid \\
\hline & Soal8 & 0.301 & .819 & Valid \\
\hline & Soal9 & 0.301 & .759 & Valid \\
\hline & Soal10 & 0.301 & .732 & Valid \\
\hline & Soal11 & 0.301 & .704 & Valid \\
\hline & Soal12 & 0.301 & .807 & Valid \\
\hline & Soal13 & 0.301 & .580 & Valid \\
\hline & Soal14 & 0.301 & .163 & Tidak Valid \\
\hline & Soal15 & 0.301 & .731 & Valid \\
\hline
\end{tabular}

Sumber: Data primer olahan, 2015

Dari hasil uji validitas dapat diketahui besarnya koefisien korelasi dari seluruh butir pertanyaan terdiri dari 9 butir pertanyaan untuk variabel tunjangan fungsional pustakawan $\left(\mathrm{X}_{1}\right), 16$ butir pertanyaan untuk variabel usia pensiun lebih lama $\left(\mathrm{X}_{2}\right)$, dan 15 butir pertanyaan variabel motivasi menjadi pustakawan (Y). Dari hasil perhitungan koefisien korelasi $\left(\mathrm{r}_{\mathrm{xy}}\right) 9$ butir pertanyaan variabel tunjangan fungsional pustakawan mempunyai $r_{\text {hitung }}$ yang lebih besar dari $r_{\text {tabel }}$ 0.301. Dengan demikian 9 item pertanyaan variabel tunjangan fungsional 
pustakawan seluruhnya layak digunanakan untuk penelitian selanjutnya. Artinya kuesioner yang digunakan dalam penelitian ini 9 butir pertanyaan tunjangan fungsional pustakawan telah memiliki ketepatan dalam pengukuran variabel, sehingga tidak ada perbedaan persepsi yang diterima responden terhadap arti masing-masing item pertanyaan. Sementara untuk kedua variabel, yaitu variabel usia pensiun lebih lama $\left(\mathrm{X}_{2}\right)$ dari 16 butir pertanyaan dan variabel motivasi menjadi pustakawan $(\mathrm{Y})$ terdiri atas 15 butir pertanyaan memiliki nilai $r_{\text {hitung }}$ yang lebih besar dari $r_{\text {tabel }}$, dan di masing-masing variabel $\left(\mathrm{X}_{2}\right.$ dan $\left.\mathrm{Y}\right)$ ada 1 butir pertanyaan mempunyai $r_{\text {hitung }}$ yang lebih kecil dari $r_{\text {tabel }}$ $(0.253<0.301)$ yaitu butir pertanyaan nomor $1\left(\mathrm{X}_{2}\right)$ dan 1 pertanyaan mempunyai $r_{\text {hitung }}$ yang lebih kecil dari $\mathrm{r}_{\text {tabel }}(0.163<0.301)$ variabel motivasi menjadi pustakawan yaitu nomor 14 (Y) tidak layak untuk digunakan untuk penelitian berikutnya. Dengan demikian 15 item pertanyaan dari variabel $\mathrm{X}_{2}$ dan 14 item pertanyaan dari variabel $\mathrm{Y}$ layak digunakan untuk penelitian selanjutnya. Artinya kuesioner yang digunakan dalam penelitian ini 15 butir pertanyaan usia pensiun lebih lama dan 14 butir pertanyaan motivasi menjadi pustakawan telah memiliki ketepatan dalam pengukuran variabel, sehingga tidak ada perbedaan persepsi yang diterima responden terhadap arti masing-masing item pertanyaan.

\section{Uji Reliabilitas}

Uji Reliabilitas dilakukan untuk mengetahui sejauh mana alat ukur dapat memberikan hasil yang konsisten bila digunakan untuk mengukur obyek yang sama dengan alat ukur yang sama. Teknik yang digunakan untuk menilai reliabilitas adalah Cronbach's Alpha $(\alpha)$, dengan cara menyebarkan angket/kuesioner kepada Tenaga Kependidikan S1 non Pustakawan Universitas A. Suatu instrumen penelitian dapat dikatakan reliabel (andal), jika alpha $(\alpha)$ lebih dari 0,6 (Ghozali, 2005: 42). Hasil pengujian reliabilitas dapat disajikan pada tabel berikut:

\begin{tabular}{|c|c|c|c|}
\hline Variabel & $\begin{array}{l}\text { Koef. Alpha } \\
\text { Cronbach }(\alpha)\end{array}$ & $\begin{array}{l}\text { Nilai } \\
\text { Kritis }\end{array}$ & Keterangan \\
\hline $\begin{array}{l}\text { Tunjangan } \\
\text { Fungsional }\end{array}$ & 0.720 & 0.6 & Reliabel \\
\hline $\begin{array}{l}\text { Usia Pensiun } \\
\text { Lebih Lama }\end{array}$ & 0.732 & 0.6 & Reliabel \\
\hline $\begin{array}{l}\text { Motivasi Menjadi } \\
\text { Pustakawan }\end{array}$ & 0.771 & 0.6 & Reliabel \\
\hline
\end{tabular}

Sumber : Data primer olahan, 2015
Tabel 10 di atas, dapat diketahui bahwa nilai koefisien Cronbach's Alpha ( $\alpha$ ), seluruh variabel lebih besar dari 0.6. Dengan demikian maka seluruh butir pertanyaan dalam variabel penelitian memiliki tingkat keandalan dalam kriteria tinggi. Sehingga butir-butir pertanyaan dalam variabel penelitian dapat digunakan untuk penelitian selanjutnya.

\section{Analisis Korelasi dan Uji Hipotesis Analisis Korelasi}

Tabel 11 Analisis Korelasi

\begin{tabular}{llrrr}
\hline & Y & X1 & X2 \\
\hline \multirow{3}{*}{ Pearson Correlation } & 1 &, $372^{*}$ &, $441^{* *}$ \\
Sig. (2-tailed) & &, 014 &, 003 \\
& N & 43 & 43 & 43 \\
\hline \multirow{2}{*}{ Pearson Correlation } &, $372^{*}$ & 1 &, 253 \\
X1 & Sig. (2-tailed) &, 014 & &, 101 \\
& N & 43 & 43 & 43 \\
\hline \multirow{2}{*}{ Pearson Correlation } &, $441^{* *}$ &, 253 & 1 \\
X2 & Sig. (2-tailed) &, 003 &, 101 & \\
& N & 43 & 43 & 43 \\
\hline *. Correlation is significant at the 0.05 level (2-tailed). \\
**. Correlation is significant at the 0.01 level (2-tailed).
\end{tabular}

Nilai signifikansi dari table 9 diatas diketahui bahwa korelasi antara variabel $\mathrm{X}_{1}$ (Tunjangan Jabatan Fungsional Pustakawan) dengan variabel $\mathrm{X}_{2}$ (Usia Pensiun Lebih Lama) nilai signifikansinya $0.101>0.05$ ( 0.101 lebih besar dari 0.05$)$ yang berarti tidak ada korelasi (hubungan) yang signifikan. Selanjutnya korelasi antara variabel $\mathrm{X}_{1}$ (Tunjangan Jabatan Fungsional Pustakawan) dengan variabel Y (Motivasi Menjadi Pustakawan) nilai signifikansinya $0.014<0.05(0.014$ lebih kecil dari 0.05 ) yang berarti ada korelasi (hubungan) yang signifikan. Yang terakhir korelasi antara variabel $\mathrm{X}_{2}$ (Usia Pensiun Lebih Lama) dengan variabel Y (Motivasi Menjadi Pustakawan) nilai signifikansinya $0.003<0.05(0.003$ lebih kecil dari 0.05 ) yang berarti ada korelasi (hubungan) yang sangat signifikan. Adapun besarnya hubungan antara variabel tunjangan fungsional pustakawan dengan motivasi menjadi pustakawan sebesar $37,2 \%$, sedangkan untuk variabel usia penisun lebih lama dengan motivasi menjadi pustakawan sebesar $44,10 \%$, dimana hubungan ini dalam kategori sedang.

Adanya hubungan dalam kategori sedang antara tunjangan fungsional dengan motivasi menjadi pustakawan menunjukkan bahwa semakin baik tunjangan fungsional pustakawan yang ada pada Universitas A, maka semakin besar motivasi 
menjadi pustakawan Universitas A. Adanya hubungan dalam kategori sedang antara usia ension lebih lama dengan motivasi menjadi pustakawan menunjukkan bahwa semakin tinggi usia ension pustakawan yang ada pada Universitas A, maka semakin besar motivasi untuk menjadi pustakawan Universitas A.

\section{Uji Hipotesis}

Penelitian dengan judul Pengaruh Tingginya Tunjangan Fungsional dan Usia Pensiun Lebih Lama Dengan Motivasi Menjadi Pustakawan, Studi Kasus: Tenaga Kependidikan Non Pustakawan Universitas A, telah dirumuskan hipotesis sebagai berikut:

$\mathrm{H}_{0}$ : Tunjangan jabatan fungsional pustakawan dan batas usia ension yang lebih lama tidak berpengaruh terhadap motivasi tenaga kependidikan non fungsional Universitas A untuk menjadi pustakawan.

H1: Tunjangan jabatan fungsional pustakawan dan batas usia ension yang lebih lama berpengaruh terhadap motivasi tenaga kependidikan non fungsional Universitas A untuk menjadi pustakawan.

Dari Tabel 11 (Analisis Korelasi) di atas menunjukkan bahwa dari kedua variabel bebas $\mathrm{X}_{1}$ dan $X_{2}$ terdapat hubungan yang signifikan dengan variabel terikat $(\mathrm{Y})$, dengan data korelasi antara variabel $\mathrm{X}_{1}$ (Tunjangan Jabatan Fungsional Pustakawan) dengan variabel Y (Motivasi Menjadi Pustakawan) nilai signifikansinya $0.014<0.05$ (0.014 lebih kecil dari 0.05) yang berarti ada korelasi (hubungan) yang signifikan. Selanjutnya korelasi antara variabel $\mathrm{X}_{2}$ (Usia Pensiun Lebih Lama) dengan variabel $Y$ (Motivasi Menjadi Pustakawan) nilai signifikansinya $0.003<0.05$ (0.003 lebih kecil dari 0.05) yang berarti ada korelasi (hubungan) yang sangat signifikan.

Dengan hasil hitungan korelasi tersebut, maka dapat diambil kesimpulan bahwa dalam penelitian ini menerima $\mathrm{H}_{1}$ dan menolak $\mathrm{H}_{0}$, artinya tunjangan jabatan fungsional pustakawan dan batas usia ension yang lebih lama berpengaruh terhadap motivasi tenaga kependidikan non fungsional Universitas A untuk menjadi pustakawan.

\section{Pembahasan}

Penelitian ini dimaksudkan untuk mencari Pengaruh Tingginya Tunjangan Fungsional Dan Usia Pensiun Lebih Lama Dengan Motivasi Menjadi Pustakawan, Studi Kasus: Tenaga Kependidikan non
Pustakawan Universitas A. Setelah dilakukan proses pengolahan data diperoleh hasil yang mendukung hipotesis. Berdasarkan nilai signifikansi diketahui bahwa korelasi antara variabel $\mathrm{X}_{1}$ (Tunjangan Jabatan Fungsional Pustakawan) dengan variabel $\mathrm{X}_{2}$ (Usia Pensiun Lebih Lama) nilai signifikansinya $0.101>0.05$ ( 0.101 lebih besar dari 0.05$)$ yang berarti tidak ada korelasi (hubungan) yang signifikan. Selanjutnya korelasi antara variabel $\mathrm{X}_{1}$ (Tunjangan Jabatan Fungsional Pustakawan) dengan variabel Y (Motivasi Menjadi Pustakawan) nilai signifikansinya $0.014<0.05(0.014$ lebih kecil dari 0.05 ) yang berarti ada korelasi (hubungan) yang signifikan. Yang terakhir korelasi antara variabel $\mathrm{X}_{2}$ (Usia Pensiun Lebih Lama) dengan variabel Y (Motivasi Menjadi Pustakawan) nilai signifikansinya $0.003<0.05(0.003$ lebih kecil dari 0.05 ) yang berarti ada korelasi (hubungan) yang sangat signifikan. Adapun besarnya hubungan antara variabel tunjangan fungsional pustakawan dengan motivasi menjadi pustakawan sebesar $37,2 \%$, sedangkan untuk variabel usia penisun lebih lama dengan motivasi menjadi pustakawan sebesar $44,10 \%$, dimana hubungan ini dalam kategori sedang.

Pengaruh variabel tunjangan fungsional dalam penelitian ini selaras dengan hasil penelitian Saputri (2016) yang menjelaskan bahwa variabel kompensasi mempunyai pengaruh secara simultan terhadap motivasi kerja Karyawan pada Rumah Sakit "JIH" Yogyakarta, variabel kompensasi mempunyai pengaruh signifikan terhadap Kinerja Karyawan pada Rumah Sakit "JIH" Yogyakarta.

Kontribusi pengaruh dari variabel tunjangan fungsional terhadap motivasi menjadi pustakawan bagi tenaga kependidikan Universitas A adalah sebesar $37,2 \%$, dan variabel usia pensiun terhadap motivasi menjadi pustakawan sebesar $44,10 \%$ menunjukkan dalam kategori sedang. Artinya pengaruh dari kedua variabel tersebut untuk menjadi pustakawan tidak terlalu signifikan. Hal ini sejalan dengan hasil jawaban responden, bahwa dari jawaban mereka diperoleh hasil bahwa responden yang menyatakan tidak berminat menjadi pustakawan sebanyak 24 orang $\mathbf{( 5 5 . 8 1 \% )}$ terdiri dari laki-laki 15 orang $(34.88 \%)$ dan perempuan 9 orang $(20.93 \%)$, yang menyatakan ragu-ragu 12 orang $(\mathbf{2 7 . 9 1} \%)$ terdiri atas laki-laki 7 orang $(16.28 \%)$ dan perempuan 5 orang (11.63\%), menyatakan minat sebanyak 4 orang $(\mathbf{9 . 3 0} \%)$ masing-masing 2 orang laki-laki dan wanita 2 orang $(4.65 \%)$, dan menyatakan abstein sebesar 3 orang $(6.97 \%)$ laki-laki 1 orang $(2.33 \%)$ dan perempuan 2 
orang (4.65\%). Dari data ini apabila dikelompokkan menjadi dua kelompok saja, yaitu kelompok yang berminat dan tidak berminat maka dapat diinterperetasikan bahwa mayoritas tenaga kependidikan non fungsional pustakawan Universitas A (yang berpendidikan S1 non Perpustakaan) yang menunjukkan angka 24 orang $(55.81 \%)$ tidak berminat menjadi pustakawan, sementara sisanya sebanyak 19 orang $(45.19 \%)$ berminat menjadi pustakawan.

Hasil penelitian ini hampir sama dengan kasus di UNDIP Semarang sebagaimana yang dipaparkan oleh Widanarta (2011) yang mendeskripsikan bahwa secara empiris ditemukan di lapangan bahwa masih banyak petugas perpustakaan yang belum menjadi pejabat fungsional pustakawan dan rendahnya minat masyarakat untuk menjadi pustakawan. Jika tunjangan jabatan fungsional pustakawan dan batas usia pensiun yang lebih lama dianggap bernilai lebih, tentu saja para petugas perpustakaan akan termotivasi untuk menjadi pustakawan. Untuk mendapatkan jawaban tersebut masih menurut Widanarta, dia mengadakan penelitian terhadap para petugas perpustakaan non pustakawan dan pustakawan di lingkungan UPT Perpustakaan UNDIP. Metode yang digunakan dalam penelitian ini adalah metode survei dengan pendekatan kuantitatif. Sehingga data yang dihasilkan dapat diolah dan dianalisis dengan menggunakan metode statistik. Rumus yang digunakan adalah Korelasi Product Moment, Korelasi Ganda dan Uji Signifikansi F. Teknik pengumpulan data yang digunakan adalah dengan menggunakan kuesioner, dan studi pustaka. Dari hasil analisis data dapat diambil kesimpulan bahwa terdapat perbedaan antara hasil analisis untuk pustakawan dan non pustakawan, yaitu : 1 . Untuk pustakawan, terdapat pengaruh yang positif dan signifikan antara tunjangan jabatan fungsional pustakawan dan batas usia pensiun terhadap motivasi menjadi pustakawan. Hal ini dibuktikan oleh nilai korelasi ganda (R) sebesar 0,735 dan nilai $F$ hitung sebesar 9,418 dengan sig sebesar 0,002 . Dimana nilai $\mathrm{F}$ hitung $(9,418)>\mathrm{F}$ tabel $(3,63)$ dan nilai sig $(0,002)<0,05$, yang berarti signifikan. 2. Untuk non pustakawan, tidak terdapat pengaruh yang positif dan signifikan antara tunjangan jabatan fungsional pustakawan dan batas usia pensiun terhadap motivasi menjadi pustakawan. Hal ini dibuktikan oleh nilai korelasi ganda (R) sebesar 0,418 dan nilai $F$ hitung sebesar 1,166 dengan sig sebesar 0,347 . Dimana nilai $\mathrm{F}$ hitung $(1,166)<$ F tabel $(3,98)$ dan nilai sig $(0,347)>$ 0,05 , yang berarti tidak signifikan. Dari hasil kedua penelitian tersebut (kasus Universitas A dan kasus yang terjadi di UNDIP) bahwa responden non pustakawan kurang berminat menjadi pustakawan.

\section{E. KESIMPULAN \\ Kesimpulan}

Dari pembahasan tersebut, maka penulis dapat menyimpulkan bahwa:

1. Tunjangan jabatan fungsional pustakawan berpengaruh positif terhadap motivasi tenaga kependidikan non pustakawan Universitas A untuk menjadi pustakawan, yang berarti ada korelasi (hubungan) yang signifikan.

2. Batas usia pensiun pustakawan yang lebih lama berpengaruh positif terhadap motivasi tenaga kependidikan non pustakawan Universitas A untuk menjadi pustakawan, yang berarti ada korelasi (hubungan) yang sangat signifikan .

3. Tunjangan jabatan fungsional pustakawan tidak ada pengaruh yang signifikan dengan batas usia pensiun, yang berarti tidak ada korelasi (hubungan) yang signifikan.

4. Tunjangan jabatan fungsional pustakawan dan batas usia pensiun yang lebih lama berpengaruh positif terhadap motivasi tenaga kependidikan non pustakawan Universitas A untuk menjadi pustakawan, artinya ada korelasi (hubungan) yang signifikan.

5. Menerima hipotesis $\mathrm{H}_{1}$ dan menolak hipotesis $\mathrm{H}_{0}$ yang menyatakan $\mathrm{H}_{0}$ : Tunjangan jabatan fungsional pustakawan dan batas usia pensiun yang lebih lama tidak berpengaruh terhadap motivasi tenaga kependidikan non fungsional Universitas A untuk menjadi pustakawan. H1: Tunjangan jabatan fungsional pustakawan dan batas usia pensiun yang lebih lama berpengaruh terhadap motivasi tenaga kependidikan non fungsional Universitas A untuk menjadi pustakawan.

\section{Saran}

Dari uraian tersebut, maka dapat diberikan saran sebagai berikut:

1. Universitas A sudah saatnya menambah jumlah pustakawan minimal 7 orang, sehingga jumlahnya menjadi menjadi 13 orang pustakawan minimal berpendidikan S1 Ilmu Perpustakaan dan Sarjana S1 Ilmu non Perpustakaan ditambah sertifikat CPTA. Hal ini dapat dilakukan dengan cara merekrut pegawai tetap Universitas A yang telah berpendidikan 
minimal Sarjana (S1) yang telah terjaring dalam penelitian ini yang berminat menjadi pustakawan sebanyak 19 orang.

2. Untuk peneliti selanjutnya, disarankan untuk meneliti dengan tema yang sama dengan melibatkan tenaga kependidikan non fungsional pustakawan yang berpendidikan Diploma 3 dan Sarjana (S1).

\section{DAFTAR PUSTAKA}

Ghozali, Imam. (2002). Aplikasi Analisis Multivariat dengan Program SPSS. Semarang: Badan Penerbit Universitas Dipenogoro.

Gomes, Faustino Cardoso. (2003). Manajemen Sumber Daya Manusia. Yogyakarta: Andi Offset.

Hasan, M Iqbal. (2002). Pokok-pokok Materi Metodologi Penelitian dan Aplikasinya. Jakarta: Ghalia Indonesia.

Indonesia. (2002). Keputusan Menteri Pendayadunaan Aparatur Negara Nomor 132/KEP/M.PAN/12/2002 tentang Jabatan Fungsional Pustakawan Dan Angka Kreditnya.

Indonesia. (2003). Keputusan Presiden Republik Indonesia Nomor 102 Tahun 2003 tentang Perubahan Atas Keputusan Presiden Nomor 64 Tahun 1992 tentang Perpanjangan Batas Usia Pensiun Pegawai Negeri Sipil yang Menduduki Jabatan Pustakawan sebagaimana telah Diubah dengan Keputusan Presiden Nomor 147 Tahun 2000.

Indonesia. (1992). Keputusan Presiden Republik Indonesia Nomor 65 Tahun 1992 tentang Tunjangan Jabatan Pustakawan, Teknisi Penerbangan, Penguji Mutu Barang, dan Pranata Komputer.

Indonesia. (2000). Keputusan Presiden Republik Indonesia Nomor 146 Tahun 2000 tentang Tunjangan Jabatan Fungsional Pustakawan.

Indonesia. (2000). Keputusan Presiden Republik Indonesia Nomor 147 Tahun 2000 tentang Perubahan Atas Keputusan Presiden Nomor 64 Tahun 1992 tentang Perpanjangan Batas Usia Pensiun Pegawai Negeri Sipil yang Menduduki Jabatan Pustakawan sebagaimana telah Diubah dengan Keputusan Presiden Nomor 147 Tahun 2000.
Indonesia. (2003). Keputusan Presiden Republik Indonesia Nomor 86 Tahun 2003 tentang Tunjangan Jabatan Fungsional Pustakawan.

Indonesia. (2014) Peraturan Menteri Pendayagunaan Aparatur Negara dan Reformasi Birokrasi Republik Indonesia Nomor 9 Tahun 2014 Tentang Jabatan Fungsional Pustakawan Dan Angka Kreditnya.

Indonesia. (2006). Peraturan Presiden Republik Indonesia Nomor 40 Tahun 2006 tentang Tunjangan Jabatan Fungsional Arsiparis dan Pustakawan.

Indonesia. (2007). Peraturan Presiden Republik Indonesia Nomor 47 Tahun 2007 tentang Tunjangan Jabatan Fungsional Pustakawan.

Indonesia. (2013). Peraturan Presiden Republik Indonesia Nomor 71 Tahun 2013 tentang Tunjangan Jabatan Fungsional Pustakawan

Indonesia. (2007). Surat Edaran Direktorat Jenderal Perbendaharaan Depkeu RI Nomor SE-70/PB/2007 Tentang Tunjangan Jabatan Fungsional Pustakawan.

Indonesia. (2007). Undang-undang Nomor 43 Tahun 2007 tentang Perpustakaan.

Indonesia. (2007). Undang-Undang Republik Indonesia No. 43 Tahun 2007 tentang Perpustakaan

Indonesia. (1969). Undang-undang Nomor 11 Tahun 1969 tentang Pensiun Pegawai dan Pensiun Janda/Dudanya PNS pasal 9.

Martoyo, Susilo. (1990). Manajemen Sumber Daya Manusia Edisi 2. Yogyakarta: BPEE.

Riduwan, (2003). Skala Pengukuran Variabelvariabel Penelitian. Bandung: Alfabeta.

Saputri, Riandiani Surya. (2016). Pengaruh Kompetensi dan Kompensasi Terhadap Kinerja dengan Motivasi Sebagai Variabel Intervening Studi Kasus Pada Rumah Sakit JIH, Tesis. Yogyakarata: Program Magister Psikologi Profesi FPSB UII.

Saputro, Romi Febriyanto. (2006). Menjadi Pustakawan, Mengapa Takut?.Pada http://gubug.sabda.org/menjadi_pustakawan mengapa_takut, tanggal 24 Februari $201 \overline{5}$ Pukul 09:18.

Sardiman A.M. (1988). Interaksi dan Motivasi Belajar Mengajar :Pedoman Bagi Guru dan Calon Guru. Jakarta : Rajawali Press. 
Siagian, Sondang P. (1989). Teori Motivasi dan Aplikasinya. Jakarta : Bina Aksara.

Singarimbun, Masri. (1994). Metode Penelitian Survai. Jakarta: LP3ES.

Soeatminah. (2002). Perpustakaan Kepustakawanan dan Pustakawan. Yogyakarta: Kanisius.

Subid Pensiun. (2011). Pensiun. Pada http://bkd.kuningankab.go.id/pensiun pada tanggal 4 Mei 2011.

Sulistyo-Basuki. (2010). Pengantar Ilmu Perpustakaan. Jakarta: Universitas Terbuka.

Tayibnapis, Burhanudin A. (1994). Administrasi Kepegawaian: Suatu Tinjauan Analitik. Jakarta: Pradnya Paramita.
Universitas Islam Indonesia. (2010). Peraturan Universitas Nomor 15/PU/REK/IX/2010 Tentang Jabatan Fungsional, Pangkat dan Angka Kredit Pustakawan Universitas Islam Indonesia. 22 September 2010

Usman, Moh Azer. (2001). Menjadi Guru Profesional. Bandung: Remaja Rosdakarya.

Widanarta, Dian. (2011). Pengaruh Tunjangan Jabatan Fungsional Pustakawan dan Batas Usia Pensiun terhadap Motivasi Petugas Perpustakaan untuk Menjadi Pustakawan di Unit Pelaksana Teknis (UPT) Perpustakaan Universitas Diponegoro. Skripsi Tidak Diterbitkan. Semarang: UNDIP.

Winardi. (2002). Motivasi dan Pemotivasian dalam Manajemen. Jakarta: Raja Grafindo Persada. 